\title{
The significance and influence of religions and confessions on the formation of nations in Bosnia and Herzegovina
}

Antonio Pehar, PhD

Herzegovina University, BiH

\begin{abstract}
The article deals with the religious and confessional identity of the population in Bosnia and Herzegovina at the time of Ottoman and then the Austro-Hungarian authorities, and it is trying to define the elements of nationality in their identity. The reasons for initiating the rounding-up of three national identities in Bosnia and Herzegovina (Muslim/Bosniak, Croatian and Serbian) and not a common one are also highlighted. It identifies the external factors as well as the circumstances of the internal dynamics of society that have influenced the formation of the nation on the dominant principle of religious/confessional affiliation of the population.
\end{abstract}

Keywords: Bosnia and Herzegovina; religion; confession; Catholicity; Orthodoxy; Islam; millet; nation.

\section{Introduction}

Relationship between religion and nation can be considered as a relationship between the universal idea and the partial community or as a universal community in the sky and the particular community on the earth. Religion is a long and durable category that affects social life, and national feeling is more superficial and occurs in a complex of social environment motivated by political and economic factors. Bearing this in mind, it is impossible to take religion as a basis for the constitution of nations. However, it is possible that religion as an institution plays a crucial role in the ethnic differentiation of the population. Religion does not give answers only to anthropological questions, but it is the organizer of collective rituals and thus structures relationships in a particular community.

When thinking of what the nation is in the modern sense of the word, it is usually thought of a model of a previously established European nation. In this model, the religious factor is insignificant. Namely, in developed European countries language has played a significant role in the constitution of nations. In Bosnia-Herzegovina area the role of language was took over by religion/confessions, which in every sense played a prominent role in closed agrarian societies.

Max Weber also found that a belief in a common origin based on the similarity of customs, language and culture creates an exceptional "sense of ethnic honor" by 
which the unity of a heterogeneous community is established. He also argued that similarity of origin is not enough to create a nation. To these Weber's assertions it is worth of adding that in the process of its formation each national community depends on the spirituality potentials expressed in the people in question.

On the feudal structures of society in the civilization framework that was strongly influenced by religious influence, the ethnic specialty of the population in Bosnia and Herzegovina was born, developed and transformed. Before the establishment of the Ottoman Empire, it is possible to speak exclusively of religious rather than of national divisions of population - Catholics, Orthodox and Bosnian krstijans. With the arrival of the Ottoman Empire, a socio-political structure is established based on the values of Islamic civilization. Thus, the new state organization has created a ground for a new ethnic differentiation.

Namely, the religions in the area of Bosnia and Herzegovina primarily classified the population on social, and then on a national basis. Within the feudal structure of society at that time, the antagonism between feudal lords and domestic serfs was supplemented by the opposition between the religion of the conquerors and the religion of the subjugated masses.

\section{Religious and confessional differentiation of population during the Ottoman Empire}

In the Ottoman Empire, as a theocratic empire, the basis of division among the minions was religious affiliation. Just the arrival of the Ottoman Empire on the territory of Bosnia and Herzegovina, Srećko Džaja has taken as the lower time limit of the historical periodization of the concretization of the relationship of confessionality and nationality. And, he is seeking the upper time limit in the emergence of a new spiritual historical moment by linking it to events in transition period from the 18th to the 19th century - the presence of social-reformist Napoleonic France in Dalmatia, i.e. on the western border of the Bosnian Eyalet, then the first Europeanization reforms of Sultan Selim III and then Serbian uprisings in 1804-1813 years. ${ }^{1}$ Within the feudal relations of the rulers in the Ottoman Empire, it is characteristic that the antagonism between the feudal and minions, in this case the serfs, was complemented by the opposites of the religious affiliation of the Ottoman invaders and the subjugated population. It is easy to conclude that class oppression also had a type of interreligious conflict. Then it is undeniable that the struggles of the oppressed were closely related to religion. Here is a germ of the religious foundations of national consciousness. Namely, initially in such a society there was a religious difference that arose from social relations and later crystallized into national differences, which do not mean that the phenomenon of religion and nationality completely separated. 
As a creator of social relations, Ottoman authorities has established a millet system, which was aiming to level existing internal differences in Bosnia and Herzegovina with a point on stabilizing its administration. ${ }^{2}$ This was a model for 'appeasement' of confessional communities through the assignment of certain self-government in the field of religion, tax, education, judiciary and some civic affairs. In essence, the millet communities were a kind of small theocracy, because their representatives were from religious communities, called the millet-bashi, who, besides religious, had both administrative and secular authority in the millet communities. Thus, they also had the power to enforce sanctions towards the members of the community, and at the same time they were responsible to the Empire for the behavior of their millet members, and they could also be punished for possible rebellion of members of the community. But the population of Islamic religion was not organized in the community of millet because their religious institutions were part of the state, and the state chief was also a supreme religious leader. The Millet system was certainly useful to the Ottoman authorities in resolving the interrelationships of religious groups of the population which were more divided and more closed to one another, which directly affected the cohesive in-group strengthening. The character of such relationships later influenced directly the strengthening of special collectivities and also their mutual distancing. Therefore, without any doubt, one can conclude that in the Ottoman millet system lies the beginning of all later social divisions in Bosnia-Herzegovina's history.

Identification, and thus division of population by religious affiliation, was expressed in all areas of life, not just by religious rites and customs. This division was also seen with what was predestined by millet system as in special education and judgment, but also by way of life, style of dressing, way of building houses and also in the residential neighborhoods (mahale).

In order to comfort other religious communities, the Ottoman authorities also make them deliberate concessions. To the Catholic population was given the "Ahdnamo" guarantee in $\mathbf{1 4 6 4}$ for the freedom of religion, and then the Franciscan Province of Bosnia Srebrena was created, Orthodox Patriarchy of Peć was renewed in 1557, and in 1556 a Sephardic (Jewish) municipality was established in Sarajevo.

${ }^{2}$ The Arabic term millet at the same time signifies both the nation and the confession. Compare: Mirko Mirković (1965). Pravni položaj i karakter srpske crkve pod turskom vlašću, 1459-1766, Beograd, Zavod za izdavanje udžbenika SR Srbije, pp.151-159. 
The position of the Serbian Orthodox Church during the Ottoman Empire and its impact on the ethnicization of the population

Ottoman authority had more confidence in the Serbian Orthodox Church than in Catholics who were bordered with other Catholic countries and whose religious leader was outside the boundaries of the Ottoman Empire. The legal status of the Orthodox Church was edited after the conquest of the Tsargrad (Istanbul) Mehmet II Conqueror, which in accordance with the Byzantine Emperor's ceremony personally carried out the investiture of Patriarch Gennadios Scholarios. Since then, the high clergy of the Orthodox Church have been nominated by the Turkish government as emperor beratas on the formal proposal of the Holy Synod, in which they were given with broad rights and privileges to patriarchs or other ecclesiastical priests. Berat legally secured to the high clergy the personal inviolability and exclusion from the jurisdiction of local Turkish administration, so they were given the right to claim the impost from their religious believers. In short, the Orthodox Church retained its old feudal structure legally under Turkish authorities only the role of the Byzantine Emperor was taken over by the Sultan and partly by the Patriarch of Tsargrad (Istanbul). ${ }^{3}$ In this sense, the reconstruction of the Serbian patriarchy in 1557 by the great vizier Mehmet Pasha Sokolovic, who was originally of Serbian origin, should be observed. After the establishment of the Serbian Patriarchate in 1557, the self-awareness of the Serbian Patriarchs of Peć grew strongly and their titles were constantly increasing the number of covered countries which began during the period of patriarch Arsenije III Crnojević, who was titled as 'patriarch of all Serbs, Bulgarians and Greeks, Dalmatia, Travunija, British islands and all four sides of the world', while during the period of patriarch Arsenije IV Jovanović Šakabente the Danube region, Bosnia, Herzegovina, Croatia and Timisoara Banat were also entered into titles. It is noteworthy that in the titles of patriarchs Bosnia and Herzegovina appeared only in the eighteenth century. The introduction of new areas in the patriarchal titles raises the question whether this meant merely expanding church jurisdictions to Orthodox believers or expressing the political goal of 'property enhancement' characteristic of the middle Ages. Srećko Džaja based on historical facts finds that the Serbian Orthodox Church in the Western Balkans practiced the political expansion on basis of the medieval ideology of ruling through the liturgy which was spreading the cult of the Serbian dynasty. ${ }^{4}$ In the period from the Ottoman conquest of Bosnia and Herzegovina to the reestablishment of the Peć Patriarchy in scarce historical sources, as regards the question of the existence of the Serbian Orthodox Church on the area of Bosnia and Herzegovina, the metropolitans of Herzegovina from 1508 to 1546 were mentioned on several occasions. In 1622 Hercegovačka metropolis was divided into two eparchies - a Herzegovinian with a seat in the Tvrdoš monastery

\footnotetext{
${ }^{3}$ More in: Srećko M. Džaja (1971). Katolici u Bosni i zapadnoj Hercegovini na prijelazu iz 18. u 19. stoljeće: doba fra Grge Ilijića Varešanina: (1783-1813), Zagreb, Kršćanska sadašnjost, pp.25.
}

${ }^{4}$ Srećko M. Džaja (1999). Konfesionalnost i nacionalnost Bosne i Hercegovine, Mostar, Ziral, pp.118. 
near Trebinje and half-Herzegovinian with a seat in the monastery of St. Peter on the river Lim, which was subjected to the Metropolitan of Raška in 1649. The first documented mention of Serbian Orthodox metropolis in Bosnian and Zvornik sandžak can be found in 1532. Stating this and other historical data Srećko Džaja concludes that it is not possible to establish scientifically the order of the Serbian Orthodox, Bosnian and Herzegovinian episcopates. Branislav Đurđev highlights the influence of the Serbian Orthodox Church, which during the 17th century gave political programs to all the national movements against the Ottoman Empire. In this regard, Đurđev emphasizes that the deterioration of the position of raya caused by the pressure of the Turkish state and the development of the Turkish feudalism had an impact on the church's attitudes as a whole, much sooner as the development of the Ottoman inner situation in the Ottoman state increasingly intensified religious relations and manifested much more the tendencies that in comparison with the conquered nonMuslim nations in the Ottoman state coincide class and religious differences. ${ }^{5}$

The Serbian Orthodox Church played an extremely important role in the development of the Serbian nation. It is important to convey the opinion of Stojan Novaković, who, amongst other, writes: "In order to mark the tribe and nationality with serbism, it was necessary besides the force of political to have whatever force of morality. This force had to be sought in the Serbian autocephaly church... As far as, among the Slavs on the Balkan peninsula, the Serbian state was spreading, Serbian nationality was always allied with it... The Serbian state, however, was tightly bound to its church, so that later, when the state had been conquered from the attack of Turkey, the church represented its state by its means in some form, and then, as long as it lasted itself, it became a standard-bearer of Serbism. With this firm organization of the church and the state, Serbity could spread across its original frontiers and become a guidon of all Slavic tribes between Croats and Bulgarians, so that not only older national names were finally destroyed, but in front of it also have faded and gained secondary significance many of the area names...

The position of the Catholic clergy and its impact on the ethnic identification of the population

Unlike Orthodox, Catholics for the Ottomans have been named as enemies due to neighboring predominantly Catholic countries - Hungary, Austria and Venice. However, after the conquest of Bosnia and Herzegovina, the Ottomans also incorporated Catholics into their own theocratic state organization by awarding a part of the clergy with personal and property gains, with which the believers also gained a certain degree of religious tolerance. Mehmet II the Conqueror gave the Bosnian Franciscans 
a Hatt-i sharif, the so-called Ahdnama. It should be noted that the privileges, unlike the entire Orthodox clergy, were granted only to the Franciscans, while the bishops as high clergy did not receive the Sultan berat and thus did not acquire the right to privileged status. During the Islamization process, after the Ottoman conquest of Bosnia and Herzegovina, the number of Catholics was continually shriveled, and the climax was reached during the rapid warfare of Prince Eugene Savoy through Bosnia to Sarajevo between October the 10th and November the 5th, 1697. As Prince Eugene Savoy and his army suddenly entered into the territory of Bosnia and Herzegovina, with the same speed and sudden he also withdrew from that area and made a great deal of damage to Turkish assets in the course of the departure. Afraid of retaliation for him and his army, a large number (but never accurately established) of Catholic population retreated. After the defeat under Vienna, the Ottoman Empire came in for a longer period of inactiveness, but also of its own stagnation. This period of peace between the Ottoman Empire and its neighboring Christian countries ought to be attributed to a continuous increase in the number of Catholic population during the second half of the 18th century.

The Franciscan Province of Bosnia Srebrena had a decisive role for BosnianHerzegovinian Catholicism since the middle Ages. With the fall of Bosnia and Herzegovina, under Ottoman rule, Bosnian Franciscan monasteries are treated as legitimate institutions by the legacies of the conquerors, and their guardians have the status of some kind of political representatives of Bosnian Catholics. In the period from the fifteenth to seventeenth century, the Province experienced a difficult time suffering great material losses and strong moral temptations. The Province of Bosnia Srebrena was separated from the mother provinces in Slavonia and Hungary in 1757, and it stayed only in the area inside the Turkish borders, on to three monasteries Sutjeska, Fojnica and Kreševo.

Through the centuries, the Franciscans have been trying to keep and increase their rights to further privileges, while at the same time the Ottoman officials as well as the Orthodox Vladika (Bishop) wanted to subjugate them or to severely tax. Therefore, the Franciscans often point themselves to the Tsargrad (Istanbul) fighting for official confirmation of their privileges. With the weakening of the Ottoman Empire, tax pressure was strengthened, so Sultan Mustafa III in 1765 abolished the privileges also on the part of the Bosnian Franciscans.

Pope Clement XII established the Apostolic Vicariate in Bosnia in 1735. In composition of Vicariate entered a large part of the Bosnian diocese, whose bishop resided in Đakovo since the middle of the 13th century, as well as parts of the Makarska and Split, Zagreb and Modruške diocese, while the Bishopric of Trebinje (Eastern Herzegovina) remained outside the border of Vicariate. Due to poverty and large tax benefits, Vicariate had a small number of parishes that was spatially large. In order to meet the pastoral needs of 
dispersed believers, some chapels were established in some parts of the great parishes, where the chaplains were subordinate to the parish priest of the parish concerned, and most often they were Glagolitic. Adrian Hastings notes that Catholicism played a decisive role with the Croats, and to a certain extent that was contributed with the use of Glagolitic in Church communication. ${ }^{6}$ Although the Glagolitic was not used in Zagreb or Slavonia, its use in Dalmatia can be considered important because of the border area towards Bosnia and Herzegovina and therefore closeness to impact. Unlike other Catholic churches in the west of Europe, only the Croatian clergyman was besieged for worship in the native language, which undoubtedly influenced forming of the identity.

\section{Islam and its influence on ethnic differentiation of Muslims}

The basic fact that caused the ethnic differentiation of the Muslim population, of course, was belonging to Islamic religion. It is necessary to emphasize that Islam is not only religious learning, but also a kind of 'philosophy of life'. Islam is, by virtue of its principle, "din va davla" - religion and the state, different from other religions, and also from non-religious ideologies. The Islamized population of Bosnia and Herzegovina in the circumstances of the Ottoman Theocratic Empire enjoyed the special social and economic status until the end of the 17th century. Namely, by accepting Islam, the population was separated from others by special rights, primarily in tax incentives, but also in duties such as warfare. It was understood that access to state services was largely for Muslim population. It is extremely important to emphasize, especially from a social point of view, that the largest number of Muslim peasants became free peasants during the time. The development of agrarian relations, where decisive was the process of čiflučenja (peasant's work on farm - čifluk), led to the existence of free Muslim peasants, but also of Orthodox and Catholic serfs. The long-term nature and importance of these social relationships is also witnessed by the fact that these circumstances have not changed even with the arrival of Austro-Hungary. Thus, the population census in 1910 determined that there were Muslim landowners with the serfs 19.15 percent, without the serfs 70.62 percent, and 56.65 percent from free peasants was of Islamic religion. Between plain serfs there were 73.92 percent Orthodox, 21.49 percent Catholics, and Muslims only 4.58 percent. ${ }^{7}$ Also, in the eighteenth century, after the Vienna War, it came period of a stronger connection between the Muslim population, and exclusively Christians were called as raya. Therefore, the Christians raya then begins to identify more and more Muslims with the ruling class, and thus the hatred of raya towards the rulers is oriented towards the hatred towards Muslims. Otherwise, the reason why the entire Balkans did not

\footnotetext{
${ }^{6}$ Adrian Hastings (2003). Gradnja nacionaliteta, Sarajevo, Rijeka, Buybook-Adamić, pp.124.

${ }^{7}$ Muhamed Hadžijahić (1990). Od tradicije do identiteta - Geneza nacionalnog pitanja bosanskih Muslimana, Zagreb, Islamska zajednica Zagreb, pp.109.
} 
become another Islamic country at the time of Ottoman Empire was that the Sultans had no interest in doing so.

Christians, in fact, paid more taxes, so their mass conversion to Islam would impoverish the Empire. On two occasions, in 1517 and 1647, when Porta seriously thought of violently Islamizing Balkan Christians, religious opposition was expressed on that thought based on the Quran. In fact, the Islamic law defends Muslims conversion to another faith, but does not insist that the unbelievers must turn to Islam. Even many converts had an obligation to prove that their acceptance of Islam was not motivated by material interest. ${ }^{8}$

\section{Religious/confessional and national relations after Austro-Hungarian occupation}

Immediately after the Congress of Berlin, on the basis of Article XXV of the Berlin Treaty, European forces entrusted to the Austro-Hungarian occupation mandate for Bosnia and Herzegovina that definitely implied the end of the uprisings started in 1875, which were led by Orthodox peasantry. The occupation of Bosnia and Herzegovina by the Austro-Hungarians did not pass peacefully, and the provided armed resistance had a different confessional-national structure in relation to the uprisings between 1875 and 1878. Resistance was provided by the Muslim and Serbian Orthodox population, while the Catholic segment of the Bosnian-Herzegovinian population showed a friendly mood towards the Austro-Hungarian occupation. So the confessional-national relations in Bosnia and Herzegovina by the arrival of the Christian Austro-Hungarian Monarchy entered in a new historical phase. The two basic features of occupational AustroHungarian politics were the settlement of agrarian and confessional-national relations.

Both provinces, i.e. dual country Bosnia and Herzegovina, were, at the time of AustroHungarian occupation, much neglected areas of economic and infrastructural terms. The new occupational authority was imposed first and foremost on the subject of modernization in all areas of economic, cultural and political life. However, the inhomogeneous confessional structure of the population made the intentions of the new occupying authorities to be difficult to implement. After conducted the population census, which had the confessional key in the entire Austro-Hungarian epoch as the main identification of the population, it was established that there was a great disproportion in the structure of the land distribution according to the religious affiliation of the population. It turned out that the Christian and non-Muslim population was in a seemingly weaker position, and as a necessary agrarian reform imposed itself. However, the new government sought to maintain the existing agrarian relations so as to gain the support of the Bosnian Muslim population through their landlords with the aim of permanent integration. The Bosnian Parliament, on 1911,

${ }^{8}$ Mark Mazower (2007). Balkan kratka povijest, Zagreb, Srednja Europa, pp.65. 
had promulgated a law on an optional, but not mandatory purchase of land that could have been purchased by serfs.

Regarding the approach to the confessional relations in the society, the AustroHungarian administration has had a differentiated approach. Austro-Hungarian politics according to "ethno-religious groups" was divided into three phases by Robert Donia - the first period of Benjamin Kallay ruling (chief administrator of Bosnia and Herzegovina) between 1883 and 1903; the second, from his death until the outbreak of the First World War and the third, between 1914 and 1918.

In the first period the re-establishing of religious hierarchy and the religious education was encouraged. The Kallay regime has inspired the idea of Bosniakdom as a unique ethnic framework for the population regardless of their religious or confession affiliation. With this he attempted to weaken the influence of Croatian and Serbian national ideologies. Given the influence of national ideologies on the entire South Slavic territory, Bosniakdom in practice came to a narrow circle of Muslim people of a bey's class and citizens who viewed the far-reaching potential of new opportunities. Kallay brought only to the intensification of intolerance among the ethnic segments of the Bosnian-Herzegovinian population. With this the strength of the religious component in the national profiling of Bosnian-Herzegovinian ethnicities is only confirmed.

The second period is specific by the revival of the multiparty system and the approval of religious and cultural autonomy for Orthodox and Muslims.

Through the third, or war period, the government suspected the Orthodox population to subdue the state. ${ }^{9}$

\section{Status of Serbian Orthodox Church and its promotion of Serbian national interests}

After the occupation, the Austro-Hungarian government had a purpose to subject work of Orthodox Church under its control. Until 1887, when referring to church institutions, the name was Greek-Orthodox or Eastern-Orthodox. The terms "Orthodox" and "Serbian" have become synonyms since the middle of the 19th century, when Serbian national ideology was built on the basis of Orthodox religion. The biggest advocate of the reconstruction of the Serbian Patriarchate "in other Serbian countries" was the Belgrade Metropolitan Mihajlo, although the Ecumenical Patriarchate in 1879 recognized the autocephaly of the Serbian Orthodox Church within the Serbian borders at that time. The founding of the autocephaly Orthodox Church in Bosnia and Herzegovina did not have any canonical support. Hence Austro-Hungarian diplomacy focused on negotiations with the Ecumenical Patriarch in Tsargrad (Istanbul), which

${ }_{9}^{9}$ Robert Donia (1994). Bosnia and Herzegovina: A tradition betrayed, London, C Hurst \& Co Publishers Ltd, pp.97-99. 
resulted in the conclusion of the "Declaration of the Ecumenical Patriarch in Tsargrad (Istanbul) on March the 27th, 1880, concerning the Provisional Arrangement of the Relationship of the Greek-Eastern Church in Bosnia and Herzegovina". This Declaration confirmed the former Metropolitans, and future appointments or possible shifts were to be determined by His Imperial and Royal Majesty after the names of the candidates were communicated to the Ecumenical Patriarch for the purpose of canonical formalities. ${ }^{10}$

This approach of the Austro-Hungarian authorities to the Bosnian-Herzegovinian Orthodox population with the hope of clergy loyalty has not been very successful. Namely, the Serbian Orthodox Church saw the struggle for its rights and freedom as a re-emergence of the medieval empire. Folklore and early Serbian historiography, with the help of the Serbian Orthodox Church, elevated the Battle of Kosovo in 1389 and the then collapse of Serbian statehood into a myth that became the foundation of Serbian Orthodox identity and inspiration for the fight against foreign authorities. In addition to the suppression of the Cyrillic script from everyday use, there was a ban on the use of the national name in the names of cultural and educational institutions. These were the basic reasons that in 1896 appeared the Movement of the Serbs for churchschool autonomy. The leaders of the Movement have become respectable members of the trading class. A breakthrough moment took place at the end of 1903, when the leaders of the Movement, started dropping in demands allowing the compromise solution with the Austro-Hungarian authorities. This enabled the adoption of a Decree on the Regulation of Church-School Autonomy for the Serbs in Bosnia and Herzegovina, adopted in Ecumenical Patriarchate on June the 13th, 1905. Robert Donia pointed out that organized political action on the foundations of Serbian national ideology took place at the turn of the nineteenth to the twentieth century. At the very end of the nineteenth century, encouraged by Serbs from Mostar, the movement expanded with including other church and school communities, resulting in the autonomy of the Serbian Orthodox Church and educational communities. Donia concluded that this movement brought newspapers, new leaders, and political experience and mobilized many Orthodox Christians to feel as Serbs. ${ }^{11}$

\section{The position of the Catholic Church and the profiling of the Croatian national idea}

Immediately before the occupation, criticisms on the work of the Franciscan Province, which was the only institutionalized Catholic organization in the Ottoman Epoch, appeared. These criticisms submitted to the Roman Curia with the request

\footnotetext{
${ }^{10}$ Srećko M. Džaja (2002). Bosna i Hercegovina u Austrougarskom razdoblju (1878-1918). Inteligencija između tradicije i ideologije, Mostar-Zagreb, Ziral, pp.52-53.

${ }^{11}$ Robert Donia (1994). Bosnia and Herzegovina: A tradition betrayed, London: C Hurst \& Co Publishers Ltd, pp.99-101.
} 
for establishing the regular church hierarchy was not initially accepted by Roman Cardinals. ${ }^{12}$ However, as a part of the Bosnian Franciscans was linked to South Slavic national movements, it became suspicious for the the Austro-Hungarian regime, what was subsequently the reason for later not obstructing the introduction of a regular Catholic hierarchy in Bosnia and Herzegovina. A regular Catholic hierarchy was established with the Papal bull Ex Hac Augusta on July the 5th, 1871, and a Zagreb professor of theology, Josip Stadler, who led the diocese until his death at 1918, came to the Archdiocese chair in Sarajevo. This was the beginning of Stadler's era in the history of Catholicism, but also of Croatianhood in Bosnia and Herzegovina. Archbishop Stadler has brought dynamic changes both in the ecclesiastical area and in the area of social and political life approved by the circles of the Catholic secular clergy, while the Franciscans and other circles of engaged Catholics disapproved it. The work of Archbishop Stadler eventually led to political cleavage in the Catholic corps of the population, and it also provoked the fierce reactions of the Orthodox and Muslim sides. Stadler, through the Catholic press, suggested to a part of the Catholic intelligence which insisted with the Friars on cooperation with the Muslims that: "Politics and religion are inseparable as the body and the soul, and since the separation of the soul from the body brings death to man, and the separation of the religion from politics carries within itself the danger of destroying the whole of life." ${ }^{13}$

Stadler's proposals for equalizing the position of the Catholic Church with the position of the Orthodox Church the Austro-Hungarian Empire perceived as an attempt to strengthen the role of the Catholic Church, which would hurt the proclaimed principle of inter-religious balance. Apart from the material status of both Christian churches, the favor of the Austro-Hungarian authorities on the Orthodox side can be illustrated by the fact that the name "Serbian Orthodox" in the appointment of the institution was approved in 1887, while the first Catholic school in Bosnia and Herzegovina was named Croatian only in 1917 in Čardak. ${ }^{14}$ Thus, the authorities considered as politically dangerous endeavor of Archbishop Stadler to organize a council in Sarajevo in 1902, in which theologians and bishops from the Croatian-Slavonian metropolis should participate. Finally, with his actions Archbishop Stadler blamed to the AustroHungarian Administration, but they have never succeeded in attempting to move him outside of Bosnia and Herzegovina.

The characteristic of the Austro-Hungarian epoch in Bosnia and Herzegovina can be assessed by the political disappointment of the Croatian Catholic population as a whole. Croats, as Catholics, have been hoping for the help of Catholic Vienna over the last decades of Ottoman rule.

\footnotetext{
${ }^{12}$ Đuro Kokša (1986). „Uspostava redovite hijerarhije u BiH“, in: Katolička crkva u Bosni i Hercegovini u XIX i XX stoljeću, Sarajevo, Vrhbosanska visoka teološka škola, pp.38-41.

${ }^{13}$ Vrhbosna, Vol. 23 (1909). Sarajevo, pp.21.

${ }^{14}$ Tomo Vukšić (1994). Međusobni odnosi katolika i pravoslavaca u Bosni i Hercegovini (1878-1903). Povijesno-teološki pristup, Mostar, Crkva na kamenu, pp.95-105.
} 
The Autonomous activity of the Islamic Religious Community and the ethnification of the Muslim population

Immediately before the occupation His Imperial and Royal Majesty turned to the Bosnian people with the proclamation. For Muslims, the most important part of this proclamation was the emphasis that existing laws and regulations would not be arbitrarily annulled and that customs and habits would remain protected. Indeed, the regulation of social relations has become a sensitive business for the Austro-Hungarian government due to the very fact that Islam does not know the separation between religion and the state, that is, between religion and way of life. Of course, as with Catholics and Orthodox, occupying authorities he sought to fully control the religious activities of the Islamic clergy. Four years after the establishment of the government, a non-existent instance of the spiritual grand Mufti of Muslims in Bosnia and Herzegovina (reis ul-ulema) was successfully established. At the same time, the highest spiritual council (ulema-meclisi) was established, consisting of four members and reis ul-ulema as chairman. On that occasion, the Islamic grand Mufti personally (seyhulislam) and his office (nesihat) were left out from confirmation (mensur). This avoided the grand Muftis opposition. Similarly, reform of Sharia courts and the reform of Muslim religious foundations (Vakifs) have been successfully resolved. An indispensable motive for initiating the movement of religious-educational autonomy in the Muslim population was the case of young girl Fata Omanović from Mostar, which happened in 1889, where she left home, married a Catholic, and accepted the Catholic faith. At that time Muslim movement for autonomy emerged with a demand for self-government of religious foundations (vakifs) and a teaching fund (mearif).

After the annexation the Austro-Hungarian Empire has no longer any reason to prevent the religious ties of the Muslim population with Istanbul, because this issue had lost political and constitutional significance. Therefore, by the middle of December 1908, it was approached to the final harmonization of the autonomous statute, which the emperor sanctioned on April the 15th, 1909, and it came into force on May the 1st, the same year.

\section{Final thoughts}

Described processes undoubtedly point out that religion was one of the constituent elements of national formulation and differentiation in Bosnia and Herzegovina. Of course, who played an important role in all confessions on the path of forming a national identity was a clergy whose position in society had specific characteristics. For Bosnia and Herzegovina, an important insight is given by Miroslav Hroch who, considering the social prerequisites of national revival in small European nations, also identified the role of clergy in the movements of the nation's formation: "1. Most of 
the priests lived in constant and direct contact with the people, or with members of the oppressed nation. At the same time, their position in society had certain characteristics specific for the ruling class (to what extent, it depended on religious affiliation and the position of priests in the ecclesiastical hierarchy), 2 . The priests were connected to the Church as an institution, both organizational and ideological... with that the Church had the right to oversee and limit the social activities of priests and to direct their attitude, 3. In order to be able to perform his duties the priest had to fulfill the basic precondition which was the knowledge of the language of the population among whom they lived and acted. The priests therefore knew the national language." ${ }^{\prime 15}$ The Bosnian-Herzegovinian social framework most striking, in the European context, testified the close link between national and religious through confessional, as the intensity of religious feelings among the population represented the basis of differentiation in society. In the developed Western European countries, the language played a significant role in the constitution of the nation, while its place in Bosnia-Herzegovina is occupied by a religion. Religion does not give answers to pure anthropological questions, but as organizer of the collective rituals is strongly involved in the social communities. The nations, often in search of God as an existential determinant, were creating particular religious forms closely related to their national characteristics. The already established religion is able to mark all or merely all social areas. Finally, the original differences in mentality were mainly or exclusively determined by religious or confessional factors.

Religion, therefore, was a powerful feature of the emerging national identity, leaving no room for anti-religious secularism that appeared in Western Europe. While national movements in Europe place the state at the center of the struggle for political order, on other side, religious mobilization of the Bosnian-Herzegovinian population through numerous uprisings has been directed against the state, i.e. against the strengthening of the role of the state. It can be said that religious power was a common good, creating a unique view of life's difficulties and doubts in particularly difficult times and circumstances, and it was therefore respected and accounted for by members of all faiths.

Since religion is one of the most important social phenomena, it has always had an impact on profiling all social relationships. So often in the past, what is here outlined, political interests used religious feelings, which certainly led to various social differentiations, including national ones. Bosnian-Herzegovinian nations are certainly of Slavic origin, and they have used a language that is mutually comprehensible, so the roots of their national identities should be sought in cultural models that are undoubtedly based on a religious or confessional basis. Of course, confession is not the only factor in forming national identities in Bosnia-Herzegovina. Finally, the

${ }^{15}$ Miroslav Hroch (2006). Društveni preduvjeti nacionalnih preporoda u Europi, Zagreb, Srednja Europa, pp.191. 
entire social orders at the time were founded or justified by religion. Religions are simply grown together with the historical development and cultural profiling of the population of Bosnia and Herzegovina in the way that they were first done sorting on social and then nationally basis. The antagonism between the Ottoman feudal lords and the domestic serfs was complemented by the antagonism between the religion of the conquerors and the religion of the subordinates, so libertarian activities and struggles were tied to religion. It can be said that it was also an interfaith conflict, giving history the role of the bearer of national consciousness throughout history. ${ }^{16}$

\section{Bibliography}

1. Berberović, S.(ed.), Islam u evoluciji bošnjačkog identiteta, Bošnjačka pismohrana, svezak 18, br.46, Zagreb: Bošnjačka nacionalna zajednica za Grad Zagreb i Zagrebačku županiju, 2019.

2. Bešlija, S., Istimalet - Bosna u osmanskoj političkoj strategiji (15. i 16. stoljeće), Sarajevo: Univerzitet u Sarajevu - Institut za historiju, 2017.

3. Ćimić, E., Drama A/teizacije, Sarajevo, Zagreb: Šahinpašić, 2007.

4. Donia, R., Bosnia and Herzegovina: A tradition betrayed, London: C Hurst \& Co Publishers Ltd, 1994.

5. Džaja, S. M., Bosna i Hercegovina u Austrougarskom razdoblju (1878-1918). Inteligencija između tradicije i ideologije, Mostar-Zagreb: Ziral, 2002.

6. Džaja, S. M., Katolici u Bosni i zapadnoj Hercegovini na prijelazu iz 18. u 19. stoljeće: doba fra Grge Ilijića Varešanina: (1783-1813), Zagreb: Kršćanska sadašnjost, 1971.

7. Džaja, S. M., Konfesionalnost i nacionalnost Bosne i Hercegovine, Mostar: Ziral, 1999.

8. Đurđev, B., Uloga crkve u starijoj istoriji srpskog naroda, Sarajevo: Svjetlost, 1964.

9. Hadžijahić, M., Od tradicije do identiteta - Geneza nacionalnog pitanja bosanskih Muslimana, Zagreb: Islamska zajednica Zagreb, 1990.

10. Hastings, A., Gradnja nacionaliteta, Sarajevo, Rijeka: Buybook-Adamić, 2003.

11. Hroch, M., Društveni preduvjeti nacionalnih preporoda u Europi, Zagreb: Srednja Europa, 2006.

12. Imamović, E., Porijeklo i pripadnost stanovništva Bosne i Hercegovine, Sarajevo: ART 7, 1998. 
13. Jahić, A., Vrijeme izazova - Bošnjaci u prvoj polovini XX stoljeća, Zagreb: Bošnjačka nacionalna zajednica za Grad Zagreb i Zagrebačku županiju, i Sarajevo: Bošnjački institut - Fondacija Adila Zulfikarpašića, 2014.

14. Karpat, K. H., Osmansko nasljeđe na Balkanu, Sarajevo: Connectum, 2019.

15. Kokša, Đ., „Uspostava redovite hijerarhije u BiH“, in: Katolička crkva u Bosni $i$ Hercegovini u XIX i XX stoljeću, Sarajevo, Vrhbosanska visoka teološka škola, 1986.

16. Kraljačić, M., Kalajev režim u Bosni i Hercegovini (1882-1903), Sarajevo: Veselin Masleša, 1987.

17. Kruševac, T., Bosansko-hercegovački listovi u XIX veku, Sarajevo: Veselin Masleša, 1978.

18. Madžar, B., Pokret Srba Bosne i Hercegovine za vjersko-prosvjetnu samoupravu, Sarajevo: Veselin Masleša, 1982.

19. Marsonet, Michele. "National identity and global culture." Academicus International Scientific Journal 1.01 (2010): 44-48.

20. Mazower, M., Balkan kratka povijest, Zagreb: Srednja Europa, 2007.

21. Mirković, M., Pravni položaj i karakter srpske crkve pod turskom vlašću, 14591766, Beograd: Zavod za izdavanje udžbenika SR Srbije, 1965.

22. Musaraj, Arta. "Intercultural and Interreligious Communication in the Balkan." Academicus International Scientific Journal 4.07 (2013): 36-43.

23. Novaković, S., „Neka teža pitanja srpske istorije“, in: Godišnjica Nikole Čupića, vol. XXXI, Beograd: Štampa Državne štamparije Kraljevine Jugoslavije, 1912.

24. Šehić, Z. (ur.), Zbornik radova / Međunarodna konferencija Bosna i Hercegovina u okviru Austro-Ugarske 1878-1918., Sarajevo: Filozofski fakultet, 2011.

25. Štulanović, M., Vjera i tradicija u identitetu Bošnjaka, Bihać: Islamski pedagoški fakultet, 2017.

26. Vrhbosna, Vol. 23, Sarajevo, 1909.

27. Vukšić, T., Međusobni odnosi katolika i pravoslavaca u Bosni i Hercegovini (1878-1903). Povijesno-teološki pristup, Mostar: Crkva na kamenu, 1994. 